\title{
ANALISIS KETERSEDIAAN AIR PADA DAERAH IRIGASI BLANG KARAM KECAMATAN DARUSSALAM KEBUPATEN ACEH BESAR
}

\author{
Ichsan Syahputra ${ }^{1}$, Cut Rahmawati ${ }^{2}$ \\ ${ }^{1,2)}$ Program Studi Teknik Sipil, Fakultas Teknik, Universitas Abulyatama \\ Jl. Blang Bintang Lama Km 8,5 Lampoh Keude Aceh Besar \\ email: ichsan.syahputra76@gmail.com,profestama7@yahoo.co.id
}

\begin{abstract}
Blang Karam Irrigation with a total area of $\pm 400 \mathrm{Ha}$ of rice fields have the potential to be developed which have supported such means Embung and Technical Irrigation Network. Availability of water for irrigation needs adequately met today with a reliable flow of $1.25 \mathrm{~m} 3 / \mathrm{s}$ and the need for retrieval of 2,312 liters / sec / ha on alternative cropping pattern with preparing land for 30 days and the need for making $0925 \mathrm{m3} / \mathrm{sec}$ and 1,766 ltr / $s /$ ha on alternative cropping pattern with preparing land for 45 days and the need for making $0707 \mathrm{~m} 3$ / sec. This suggests that the availability of water for Blang Karam irrigation area enough to meet the needs of the growing season irrigation water for 2 times a year.
\end{abstract}

Keywords : Availability of water, Irrigation, Embung

\begin{abstract}
Abstrak: Daerah Irigasi Blang Karam dengan luas areal persawahan \pm 400 Ha memiliki potensi untuk dikembangkan dimana telah didukung sarana seperti Embung dan Jaringan Irigasi Teknis. Ketersediaan air untuk kebutuhan irigasi saat ini cukup terpenuhi dengan debit yang dapat diandalkan sebesar $1.25 \mathrm{~m} 3 /$ det dan kebutuhan untuk pengambilan sebesar 2.312 ltr/det/ha pada alternatif pola tanam dengan penyiapan lahan selama 30 hari dan kebutuhan pengambilan $0.925 \mathrm{~m} 3 /$ det dan $1.766 \mathrm{ltr} / \mathrm{det} /$ ha pada alternatif pola tanam dengan penyiapan lahan selama 45 hari dan kebutuhan pengambilan $0.707 \mathrm{~m} 3 /$ det. Hal ini menunjukkan bahwa ketersediaan air daerah irigasi Blang Karam cukup untuk memenuhi kebutuhan air irigasi dengan masa tanam selama 2 kali dalam setahun.
\end{abstract}

Kata Kunci : Ketersediaan Air, Irigasi, Embung

Air merupakan salah satu faktor penting untuk menunjang keberhasilan di bidang pertanian khususnya untuk tanaman padi. Di samping itu sarana dan prasarana pendukung insfrastruktur untuk lahan pertanian yang terdiri dari jaringan pembawa irigasi, waduk dengan skala besar, embung dengan skala kecil dan jaringan pembuang harus selalu dalam keadaan siap pakai sehingga mampu menghantar dan menjamin kecukupan air untuk kebutuhan lahan pertanian khususnya di daerah irigasi Blang Karam. Daerah irigasi Blang Karam merupakan salah satu derah irigasi yang memiliki potensi yang cukup besar untuk di kembangkan dimana memiliki luas area \pm 400 Hektar. Dengan adanya potensi tesebut maka dapat mendukung sektor perekonomian dan memberikan harapan baru bagi masyarakat untuk terus berusaha meningkatkan kondisi sosial ekonomi masyarakat petani yang ditandai dengan indikator:

a)Berkurangnya penduduk miskin

b)Berkurangnya tingkat pengangguran

c)Meningkatnya produktivitas masyarakat

d)Meningkatnya ketertiban umum.

Sasaran dari pelaksanaan kegiatan ini adalah menganalisis ketersediaan air yang 
bersumber di embung Blang Karam dengan tujuan meningkatkan hasil panen di daerah irigasi Blang Karam dan sekitarnya.

Lokasi pekerjaan daerah irigasi Blang Karam ini berada di Kecamatan Darussalam Kabupaten Aceh Besar Provinsi Aceh, tepatnya pada posisi $5^{\circ} 26^{\prime} 22^{\prime \prime}-5^{\circ} 27^{\prime} 40^{\prime \prime}$ Lintang Utara dan $95^{\circ} 28^{\prime} 6^{\prime \prime}-95^{\circ} 29^{\prime} 48^{\prime \prime}$ Bujur Timur.

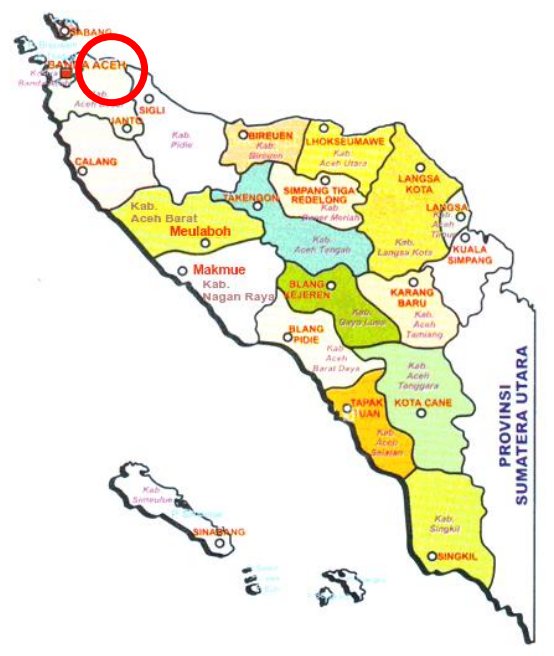

Gambar 1. Peta Lokasi Kajian

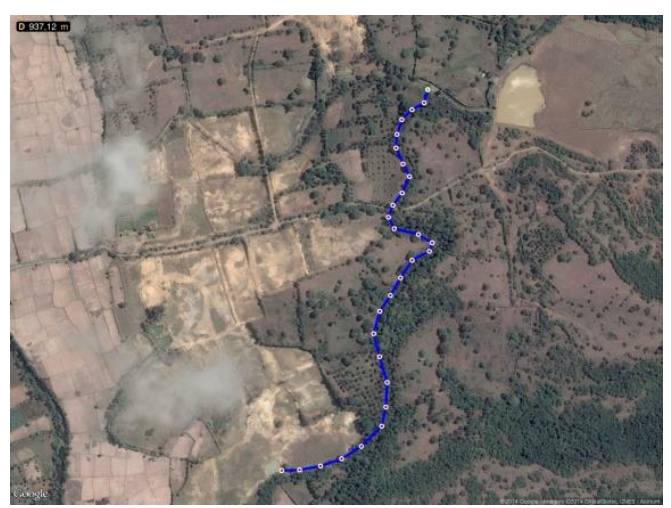

Gambar 2. Saluran Pembawa Sekunder Irigasi Blang Karam (Kiri)

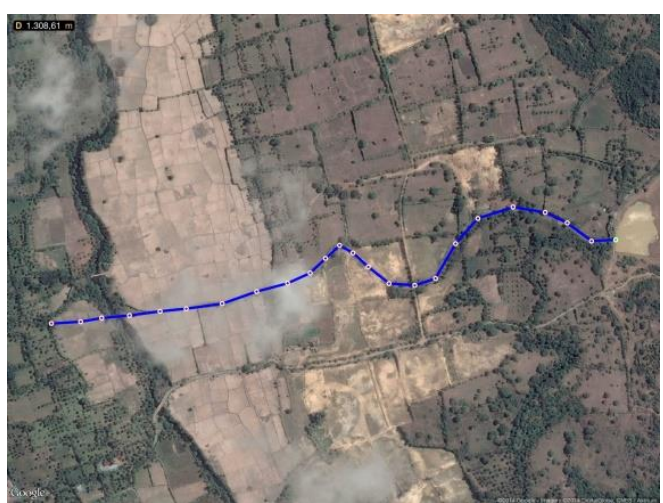

Gambar 3. Saluran Pembawa Sekunder Irigasi Blang Karam (Kanan)

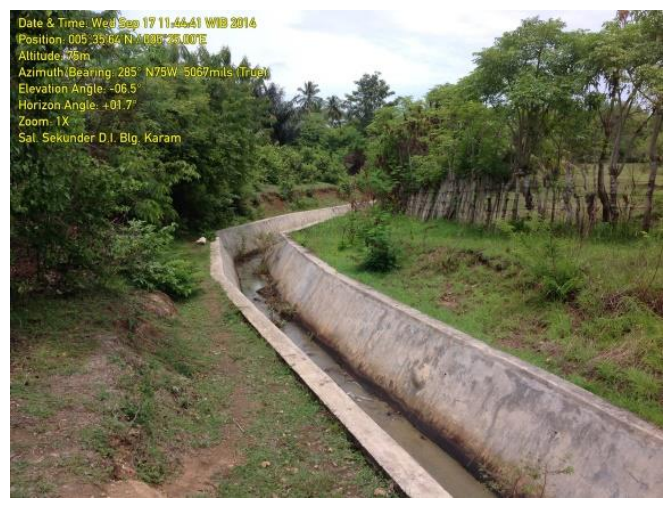

Gambar 4. Kondisi Saluran Pembawa Irigasi Blang Karam (Kanan)

\section{KAJIAN PUSTAKA}

\section{Curah Hujan}

Data curah hujan dan debit merupakan data yang paling fundamental dalam perencanaan jaringan irigasi. Ketetapan dalam memilih lokasi dan peralatan baik curah hujan maupun debit merupakan faktor yang menentukan kualitas data yang diperoleh. Analisis data hujan dimaksudkan untuk mendapatkan besaran curah hujan dan analisis statistik yang diperhitungkan dalam perhitungan debit banjir rencana. Data curah hujan yang dipakai untuk perhitungan debit banjir adalah hujan yang terjadi pada daerah aliran sungai pada waktu yang sama. Curah hujan yang diperlukan untuk penyusunan 
suatu rancangan pemanfaatan air dan rancangan pengendalian banjir adalah curah hujan rata-rata di seluruh daerah yang bersangkutan, bukan curah hujan pada suatu titik tertentu. Curah hujan ini disebut curah hujan area dan dinyatakan dalam $\mathrm{mm}$ (Sosrodarsono, 2003).

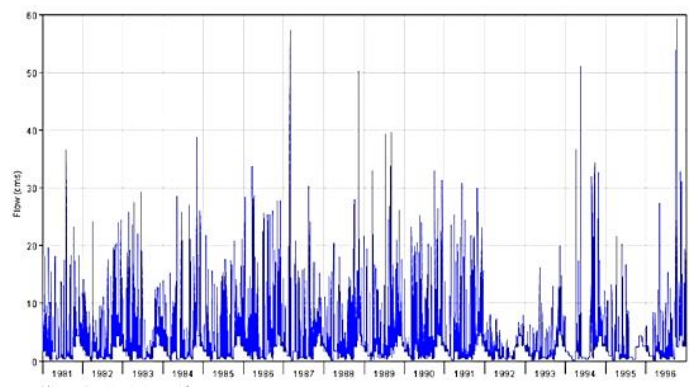

Gambar 5. Pencatatan Data Curah Hujan

\section{Ketersediaan Air}

Debit andalan merupakan debit minimal yang sudah ditentukan yang dapat dipakai untuk memenuhi kebutuhan air. Perhitungan ini menggunakan cara analisis water balance dari Dr. F.J Mock berdasarkan data curah hujan bulanan, jumlah hari hujan, evapotranspirasi dan karakteristik hidrologi daerah pengaliran. Prinsip perhitungan ini adalah bahwa hujan yang jatuh diatas tanah (presipitasi) sebagian akan hilang karena penguapan (evaporasi), sebagian akan hilang menjadi aliran permukaan (direct run off) dan sebagian akan masuk tanah (infiltrasi). Infiltrasi mula-mula menjenuhkan permukaaan (top soil) yang kemudian menjadi perkolasi dan akhirnya keluar ke sungai sebagai base flow.

\section{Kebutuhan Air Irigasi}

Kebutuhan air irigasi adalah jumlah air total yang akan diberikan pada petak sawah atau jaringan irigasi. Kebutuhan bersih air irigasi dibedakan atas dua macam, tanaman yang banyak memerlukan air dalam proses pengolahan tanah, yaitu padi dan tanaman yang tidak banyak memerlukan air dalam proses pengolahan tanah, yaitu palawija. Kebutuhan air irigasi terdiri dari kebutuhan air padi (NFR), kebutuhan air konsumtif (Etc), dan kebutuhan air untuk Palawija (NFR),

\section{Kebutuhan Air Pengambilan}

Kebutuhan pengambilan untuk tanaman adalah jumlah debit air yang dibutuhkan oleh satu hektar sawah untuk menanam padi atau palawija. Kebutuhan pengambilan ini dipengaruhi oleh efisiensi irigasi. Efisiensi irigasi ini adalah air hilang (losses) akibat dari bocoran (rembesan) dan penguapan di dalam saluran pada saat air mengalir (Anonim No. 2, 1986). Kebutuhan pengambilan yang dihasilkan untuk pola tanam yang dipakai, akan dibandingkan dengan debit andalan untuk tiap setengah bulan dan luas daerah yang bisa diairi (Anonim No. 2, 1986). Apabila debit sungai berlimpah maka luas daerah layanan irigasi adalah tetap dan direncanakan sesuai dengan pola tanam yang sesuai. Bila debit sungai terjadi kekurangan maka diperlukan alternatif rotasi teknis/golongan, luas daerah irigasi dikurangi atau melakukan modifikasi dalam pola tanam.

Debit pengambilan ditentukan oleh kebutuhan pengambilan dan luas daerah yang akan diairi. Debit pengambilan dapat dihitung 
dengan rumus (Anonim No. 3, 1986) :

$Q=\frac{D R \times A}{1000}$

Dimana :

$Q \quad=$ Debit pengambilan $(\mathrm{m} 3 /$ det $)$

$D R \quad=$ Kebutuhan pengambilan (ltr/det/ha)

$A \quad=$ Luas areal sawah $(\mathrm{Ha})$

\section{Pola Tanam}

Pola tanam disesuaikan dengan daerah studi. Pola tanam adalah penggantian berbagai jenis tanaman yang ditanam dalam waktu tertentu. Musim tanam adalah penentuan waktu untuk melakukan penanaman. Penentuan waktu untuk satu kali tanam ditentukan oleh umur dan jenis tanaman (Anonim No. 3, 1986).
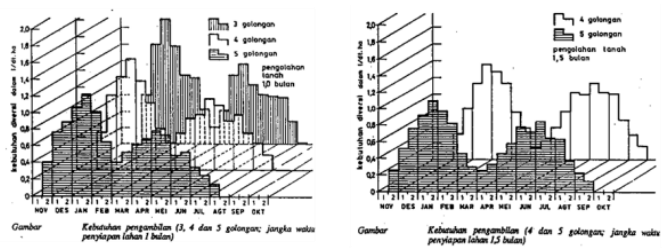

Gambar 6. Sistem Rotasi Teknis

\section{METODE PENELITIAN}

Untuk menganalisis ketersediaan air dan besarnya kebutuhan air irigasi, maka datadata yang diperlukan adalah sebagai berikut :
1) Data Curah hujan harian minimal selama 10 tahun;

2) Data Iklim yang terdiri dari suhu udara, kelembaban, tekanan udara, penyinaran matahari, penguapan, dan kecepatan angin;

3) Luas daerah irigasi;

4) Luas Daerah Aliran Sungai (DAS);

Jenis tanaman yang akan ditanam terkait dengan pola tanam.

Setelah data-data tersebut diperoleh, kemudian dilanjutkan dengan melakukan analisis hidrologi untuk mendapatkan besarnya ketersediaan air pada suatu sungai yang biasa disebut juga dengan Debit Andalan.

\section{HASIL PEMBAHASAN}

Data hidroklimatologi yang terdiri dari data curah hujan dan data iklim (suhu udara, kelembaban, penguapan, kecepatan angin) diperoleh dari Statiun BMKG Blang Bintang Kabupaten Aceh Besar tepatnya di Bandara Internasional Sultan Iskandar Muda dengan panjang data selama 10 tahun dari tahun 2000 -2010 .

Tabel 1. Data Evapotranspirasi ( $\mathrm{mm} / \mathrm{bln})$

\begin{tabular}{|c|c|c|c|c|c|c|c|c|c|c|c|}
\hline \multicolumn{10}{|c|}{ Bulan } \\
\hline Jan & Feb & Mar & Apr & Mei & Jun & Jul & Agst & Sept & Okt & Nop & Dec \\
\hline 3.81 & 4.28 & 4.32 & 4.10 & 3.19 & 4.15 & 4.14 & 4.40 & 4.30 & 3.88 & 3.74 & 3.30 \\
\hline
\end{tabular}

Tabel 2. Curah Hujan Efektif (mm)

\begin{tabular}{|c|c|c|c|c|c|c|c|c|c|c|c|c|}
\hline \multirow{2}{*}{ No. } & \multicolumn{2}{|c|}{ Jan } & \multicolumn{2}{c|}{ Peb } & \multicolumn{2}{c|}{ Mar } & \multicolumn{2}{c|}{ Apr } & \multicolumn{3}{c|}{ Mei } & \multicolumn{2}{c|}{ Jun } \\
\cline { 2 - 14 } & $\mathbf{1}$ & $\mathbf{2}$ & $\mathbf{1}$ & $\mathbf{2}$ & $\mathbf{1}$ & $\mathbf{2}$ & $\mathbf{1}$ & $\mathbf{2}$ & $\mathbf{1}$ & $\mathbf{2}$ & $\mathbf{1}$ & $\mathbf{2}$ \\
\hline $\mathrm{R} 80 \%(\mathrm{~mm} / \mathrm{b} / \mathrm{n})$ & 0.3 & 0.2 & 0.8 & 0.4 & 1.14 & 1.26 & 0.2 & 0.9 & 0.7 & 0.2 & 0.3 & 0.1 \\
\hline $\operatorname{Re}(\mathrm{mm} / \mathrm{hari})$ & 0.01 & 0.01 & 0.04 & 0.02 & 0.05 & 0.06 & 0.01 & 0.04 & 0.03 & 0.01 & 0.01 & 0.00 \\
\hline
\end{tabular}




\begin{tabular}{|l|c|c|c|c|c|c|c|c|c|c|c|c|}
\hline \multirow{2}{*}{ No. } & \multicolumn{2}{|c|}{ Jul } & \multicolumn{2}{c|}{ Agt } & \multicolumn{2}{c|}{ Sep } & \multicolumn{2}{c|}{ Okt } & \multicolumn{2}{c|}{ Nop } & \multicolumn{2}{c|}{ Des } \\
\cline { 2 - 14 } & $\mathbf{1}$ & $\mathbf{2}$ & $\mathbf{1}$ & $\mathbf{2}$ & $\mathbf{1}$ & $\mathbf{2}$ & $\mathbf{1}$ & $\mathbf{2}$ & $\mathbf{1}$ & $\mathbf{2}$ & $\mathbf{1}$ & $\mathbf{2}$ \\
\hline $\mathrm{R} 80 \%(\mathrm{~mm} / \mathrm{b} / \mathrm{n})$ & 0.1 & 0.1 & 0.1 & 0.56 & 0.46 & 0.64 & 1.14 & 1.6 & 0.88 & 1.76 & 1.3 & 0.6 \\
\hline $\operatorname{Re}(\mathrm{mm} / \mathrm{hari})$ & 0.00 & 0.00 & 0.00 & 0.03 & 0.02 & 0.03 & 0.05 & 0.07 & 0.04 & 0.08 & 0.06 & 0.03 \\
\hline
\end{tabular}

Tabel 3. Evapotranspirasi dan Perkolasi

\begin{tabular}{|c|c|c|c|c|}
\hline Bulan & $\begin{array}{c}\text { ETo } \\
\text { (mm/hari) }\end{array}$ & $\begin{array}{c}\mathrm{P} \\
(\mathrm{mm} / \mathrm{h} \text { hari) }\end{array}$ & $\begin{array}{c}\text { Re padi } \\
\text { (mm/hari) }\end{array}$ & $\begin{array}{c}\text { Re palawija } \\
\text { (mm/hari) }\end{array}$ \\
\hline Januari & 3.81 & 2.0 & $\begin{array}{l}0.0 \\
0.0\end{array}$ & $\begin{array}{l}0.1 \\
0.1\end{array}$ \\
\hline Pebruari & 4.28 & 2.0 & $\begin{array}{l}0.0 \\
0.0\end{array}$ & $\begin{array}{l}0.1 \\
0.1\end{array}$ \\
\hline Maret & 4.32 & 2.0 & $\begin{array}{l}0.1 \\
0.1\end{array}$ & $\begin{array}{l}0.1 \\
0.2\end{array}$ \\
\hline April & 4.10 & 2.0 & $\begin{array}{l}0.0 \\
0.0\end{array}$ & $\begin{array}{l}0.2 \\
0.1\end{array}$ \\
\hline Mei & 3.19 & 2.0 & $\begin{array}{l}0.0 \\
0.0\end{array}$ & $\begin{array}{l}0.2 \\
0.1\end{array}$ \\
\hline Juni & 4.15 & 2.0 & $\begin{array}{l}0.0 \\
0.0\end{array}$ & $\begin{array}{l}0.0 \\
0.0\end{array}$ \\
\hline Juli & 4.14 & 2.0 & $\begin{array}{l}0.0 \\
0.0\end{array}$ & $\begin{array}{l}0.0 \\
0.0\end{array}$ \\
\hline Agustus & 4.40 & 2.0 & $\begin{array}{l}0.0 \\
0.0\end{array}$ & $\begin{array}{l}0.1 \\
0.1\end{array}$ \\
\hline September & 4.30 & 2.0 & $\begin{array}{l}0.0 \\
0.0\end{array}$ & $\begin{array}{l}0.1 \\
0.1\end{array}$ \\
\hline Oktober & 3.88 & 2.0 & $\begin{array}{l}0.1 \\
0.1\end{array}$ & $\begin{array}{l}0.2 \\
0.1\end{array}$ \\
\hline Nopember & 3.74 & 2.0 & $\begin{array}{l}0.0 \\
0.1\end{array}$ & $\begin{array}{l}0.3 \\
0.3\end{array}$ \\
\hline Desember & 3.30 & 2.0 & $\begin{array}{l}0.1 \\
0.0 \\
\end{array}$ & $\begin{array}{l}0.2 \\
0.1\end{array}$ \\
\hline
\end{tabular}

Tabel 4. Pengaturan Jadwal Tanam

\begin{tabular}{|c|c|c|c|c|c|c|c|}
\hline $\begin{array}{c}\text { Masa } \\
\text { Penanaman }\end{array}$ & $\begin{array}{l}\text { urutan } 1 / 2 \text { bulan } \\
\text { sejak penanaman }\end{array}$ & \multicolumn{2}{|c|}{ Bulan } & $\begin{array}{c}\text { ETo } \\
\text { (mm/hari) }\end{array}$ & $\begin{array}{c}\mathrm{P} \\
\text { (mm/hari) }\end{array}$ & $\begin{array}{c}\text { Re padi } \\
\text { (mm/hari) }\end{array}$ & $\begin{array}{c}\text { Re palawija } \\
(\mathrm{mm} / \mathrm{hari})\end{array}$ \\
\hline \multirow[t]{8}{*}{ pertama } & 1 & Januari & 1 & 3.8 & 2.0 & 0.0 & 0.1 \\
\hline & 2 & & 2 & 3.8 & 2.0 & 0.0 & 0.1 \\
\hline & 3 & Pebruari & 1 & 4.3 & 2.0 & 0.0 & 0.1 \\
\hline & 4 & & 2 & 4.3 & 2.0 & 0.0 & 0.1 \\
\hline & 5 & Maret & 1 & 4.3 & 2.0 & 0.1 & 0.1 \\
\hline & 6 & & 2 & 4.3 & 2.0 & 0.1 & 0.2 \\
\hline & 7 & April & 1 & 4.1 & 2.0 & 0.0 & 0.2 \\
\hline & 8 & & 2 & 4.1 & 2.0 & 0.0 & 0.1 \\
\hline \multirow[t]{16}{*}{ kedua } & 9 & Mei & 1 & 3.2 & 2.0 & 0.0 & 0.2 \\
\hline & 10 & & 2 & 3.2 & 2.0 & 0.0 & 0.1 \\
\hline & 11 & Juni & 1 & 4.2 & 2.0 & 0.0 & 0.0 \\
\hline & 12 & & 2 & 4.2 & 2.0 & 0.0 & 0.0 \\
\hline & 13 & Juli & 1 & 4.1 & 2.0 & 0.0 & 0.0 \\
\hline & 14 & & 2 & 4.1 & 2.0 & 0.0 & 0.0 \\
\hline & 15 & Agustus & 1 & 4.4 & 2.0 & 0.0 & 0.1 \\
\hline & 16 & & 2 & 4.4 & 2.0 & 0.0 & 0.1 \\
\hline & 17 & September & 1 & 4.3 & 2.0 & 0.0 & 0.1 \\
\hline & 18 & & 2 & 4.3 & 2.0 & 0.0 & 0.1 \\
\hline & 19 & Oktober & 1 & 3.9 & 2.0 & 0.1 & 0.2 \\
\hline & 20 & & 2 & 3.9 & 2.0 & 0.1 & 0.1 \\
\hline & 21 & Nopember & 1 & 3.7 & 2.0 & 0.0 & 0.3 \\
\hline & 22 & & 2 & 3.7 & 2.0 & 0.1 & 0.3 \\
\hline & 23 & Desember & 1 & 3.3 & 2.0 & 0.1 & 0.2 \\
\hline & 24 & & 2 & 3.3 & 2.0 & 0.0 & 0.1 \\
\hline
\end{tabular}


Tabel 5. Kebutuhan Air Perhektar Sawah (mm/hari)

\begin{tabular}{|c|c|c|c|c|c|c|c|c|c|c|c|}
\hline $\begin{array}{c}\text { Masa } \\
\text { Penanaman }\end{array}$ & $\begin{array}{l}\text { urutan } 1 / 2 \text { bulan } \\
\text { sejak penanaman }\end{array}$ & \multicolumn{2}{|c|}{ Bulan } & $\begin{array}{c}\text { ETo } \\
\text { (mm/hari) }\end{array}$ & $\begin{array}{c}\mathrm{P} \\
\text { (mm/hari) }\end{array}$ & $\begin{array}{c}\mathrm{Re} \\
\text { (mm/hari) }\end{array}$ & $\begin{array}{c}\text { WLR } \\
\text { (mm/hari) }\end{array}$ & $\bar{c}$ & $\begin{array}{c}\text { ETc } \\
\text { (mm/hari) }\end{array}$ & $\begin{array}{c}\mathrm{IR} \\
(\mathrm{mm} / \mathrm{h} \text { ari) }\end{array}$ & $\begin{array}{c}\mathrm{NFR} \\
\text { (mm/hari) }\end{array}$ \\
\hline \multirow[t]{8}{*}{ pertama } & 1 & \begin{tabular}{|l} 
Januari \\
\end{tabular} & 1 & 3.8 & 2.0 & 0.0 & - & LP & 4.191 & 13.413 & 13.401 \\
\hline & 2 & & 2 & 3.8 & 2.0 & 0.0 & - & LP & 4.191 & 13.413 & 13.401 \\
\hline & 3 & Pebruari & 1 & 4.3 & 2.0 & 0.0 & 1.70 & 1.100 & 4.708 & - & 8.371 \\
\hline & 4 & & 2 & 4.3 & 2.0 & 0.0 & 1.70 & 1.075 & 4.601 & - & 8.282 \\
\hline & 5 & Maret & 1 & 4.3 & 2.0 & 0.1 & 1.70 & 1.050 & 4.536 & - & 8.183 \\
\hline & 6 & & 2 & 4.3 & 2.0 & 0.1 & 1.70 & 1.000 & 4.320 & - & 7.961 \\
\hline & 7 & April & 1 & 4.1 & 2.0 & 0.0 & - & 0.475 & 1.948 & - & 3.938 \\
\hline & 8 & & 2 & 4.1 & 2.0 & 0.0 & - & 0.000 & 0.000 & - & 1.958 \\
\hline \multirow[t]{16}{*}{ kedua } & 9 & Mei & 1 & 3.2 & 2.0 & 0.0 & - & LP & 3.509 & 11.389 & 11.368 \\
\hline & 10 & & 2 & 3.2 & 2.0 & 0.0 & - & LP & 3.509 & 11.389 & 11.368 \\
\hline & 11 & Juni & 1 & 4.2 & 2.0 & 0.0 & 1.70 & 1.100 & 4.565 & - & 8.251 \\
\hline & 12 & & 2 & 4.2 & 2.0 & 0.0 & 1.70 & 1.075 & 4.461 & - & 8.157 \\
\hline & 13 & Juli & 1 & 4.1 & 2.0 & 0.0 & 1.70 & 1.050 & 4.347 & - & 8.042 \\
\hline & 14 & & 2 & 4.1 & 2.0 & 0.0 & 1.70 & 1.000 & 4.140 & - & 7.835 \\
\hline & 15 & Agustus & 1 & 4.4 & 2.0 & 0.0 & - & 0.475 & 2.090 & - & 4.085 \\
\hline & 16 & & 2 & 4.4 & 2.0 & 0.0 & - & 0.250 & 1.100 & - & 3.074 \\
\hline & 17 & September & 1 & 4.3 & 2.0 & 0.1 & - & 0.545 & 2.344 & - & 4.243 \\
\hline & 18 & & 2 & 4.3 & 2.0 & 0.1 & - & 0.775 & 3.333 & - & 5.207 \\
\hline & 19 & Oktober & 1 & 3.9 & 2.0 & 0.2 & - & 1.005 & 3.899 & - & 5.729 \\
\hline & 20 & & 2 & 3.9 & 2.0 & 0.1 & - & 1.035 & 4.016 & - & 5.876 \\
\hline & 21 & Nopember & 1 & 3.7 & 2.0 & 0.3 & - & 0.985 & 3.684 & - & 5.432 \\
\hline & 22 & & 2 & 3.7 & 2.0 & 0.3 & - & 0.475 & 1.777 & - & 3.478 \\
\hline & 23 & Desember & 1 & 3.3 & 2.0 & 0.2 & - & 0.000 & 0.000 & - & 1.811 \\
\hline & 24 & & 2 & 3.3 & 2.0 & 0.1 & - & 0.000 & 0.000 & - & 1.881 \\
\hline
\end{tabular}

Tabel 6. Kebutuhan Pengambilan Air Irigasi (Itr/det/ha)

\begin{tabular}{|c|c|c|c|}
\hline \multicolumn{2}{|c|}{ Bulan } & $\begin{array}{c}\text { NFR } \\
\text { (mm/hari) }\end{array}$ & $\begin{array}{c}\mathrm{DR} \\
\text { (ltr/dtk/ha) }\end{array}$ \\
\hline \multirow[t]{2}{*}{ Januari } & 1 & 13.401 & 2.386 \\
\hline & 2 & 13.401 & 2.386 \\
\hline \multirow[t]{2}{*}{ Pebruari } & 1 & 8.371 & 1.491 \\
\hline & 2 & 8.282 & 1.475 \\
\hline \multirow[t]{2}{*}{ Maret } & 1 & 8.183 & 1.457 \\
\hline & 2 & 7.961 & 1.418 \\
\hline \multirow[t]{2}{*}{ April } & 1 & 3.938 & 0.701 \\
\hline & 2 & 1.958 & 0.349 \\
\hline \multirow[t]{2}{*}{ Mei } & 1 & 11.368 & 2.024 \\
\hline & 2 & 11.368 & 2.024 \\
\hline \multirow[t]{2}{*}{ Juni } & 1 & 8.251 & 1.469 \\
\hline & 2 & 8.157 & 1.452 \\
\hline \multirow[t]{2}{*}{ Juli } & 1 & 8.042 & 1.432 \\
\hline & 2 & 7.835 & 1.395 \\
\hline \multirow[t]{2}{*}{ Agustus } & 1 & 4.085 & 0.727 \\
\hline & 2 & 3.074 & 0.547 \\
\hline \multirow[t]{2}{*}{ September } & 1 & 4.243 & 0.756 \\
\hline & 2 & 5.207 & 0.927 \\
\hline \multirow[t]{2}{*}{ Oktober } & 1 & 5.729 & 1.020 \\
\hline & 2 & 5.876 & 1.046 \\
\hline \multirow[t]{2}{*}{ Nopember } & 1 & 5.432 & 0.967 \\
\hline & 2 & 3.478 & 0.619 \\
\hline \multirow[t]{2}{*}{ Desember } & 1 & 1.811 & 0.322 \\
\hline & 2 & 1.881 & 0.335 \\
\hline
\end{tabular}




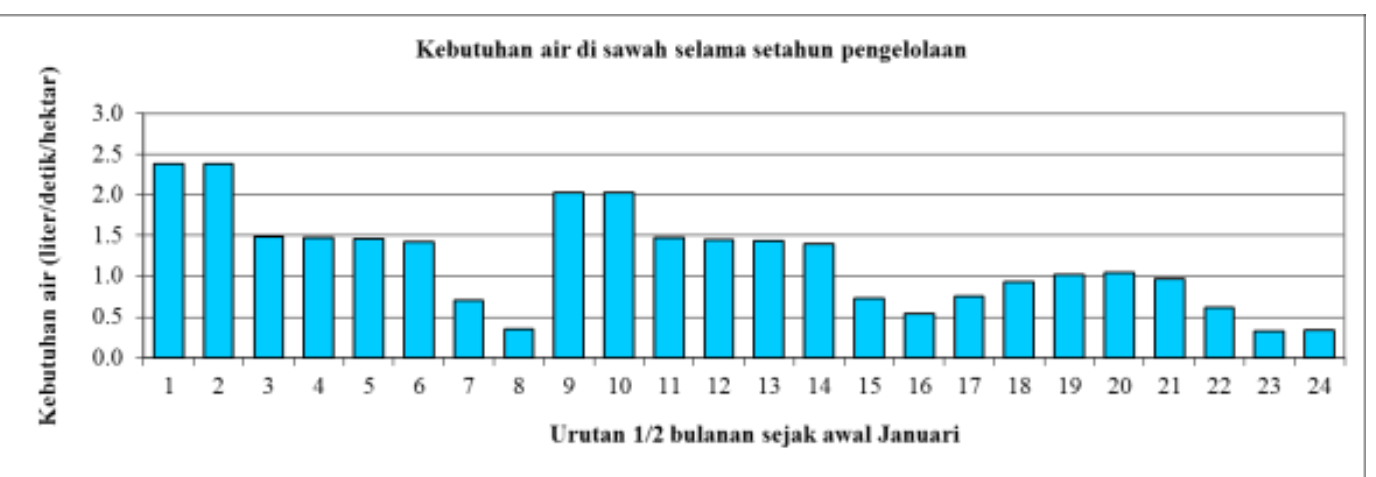

Gambar 7. Kebutuhan Pengambilan Air Irigasi (Itr/det/ha)

\begin{tabular}{|c|c|c|c|c|c|c|c|c|c|c|c|c|c|c|c|c|c|c|c|c|c|c|c|c|}
\hline Bulan & & & & & & & & & & & $\mathrm{Ju}$ & & & & Agu & & Septe & nber & Okt & & Nope & nber & Dese & mber \\
\hline Perioda $1 / 2$ bulanan & 1 & 2 & 1 & 2 & 1 & 2 & 1 & 2 & 1 & 2 & 1 & 2 & 1 & 2 & 1 & 2 & 1 & 2 & 1 & 2 & 1 & 2 & 1 & 2 \\
\hline Pola tanam cepat & $\overline{=}$ & $=$ & & & & & & 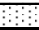 & & & & & & & & & \#曲 & \#曲 & \#曲 & \#妌 & \#曲 & 腄 & & \\
\hline Pola tanam lambat & 4 & & & & & & & & & & & & & & & & & \#帚 & 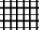 & & & 冊 & 曲 & \\
\hline Urutan $1 / 2$ bulanan & 1 & 2 & 3 & 4 & 5 & 6 & 7 & 8 & 9 & 10 & 11 & 12 & 13 & 14 & 15 & 16 & 17 & 18 & 19 & 20 & 21 & 22 & 23 & 24 \\
\hline
\end{tabular}

\section{Gambar 8. Sistem Pola Tanam}

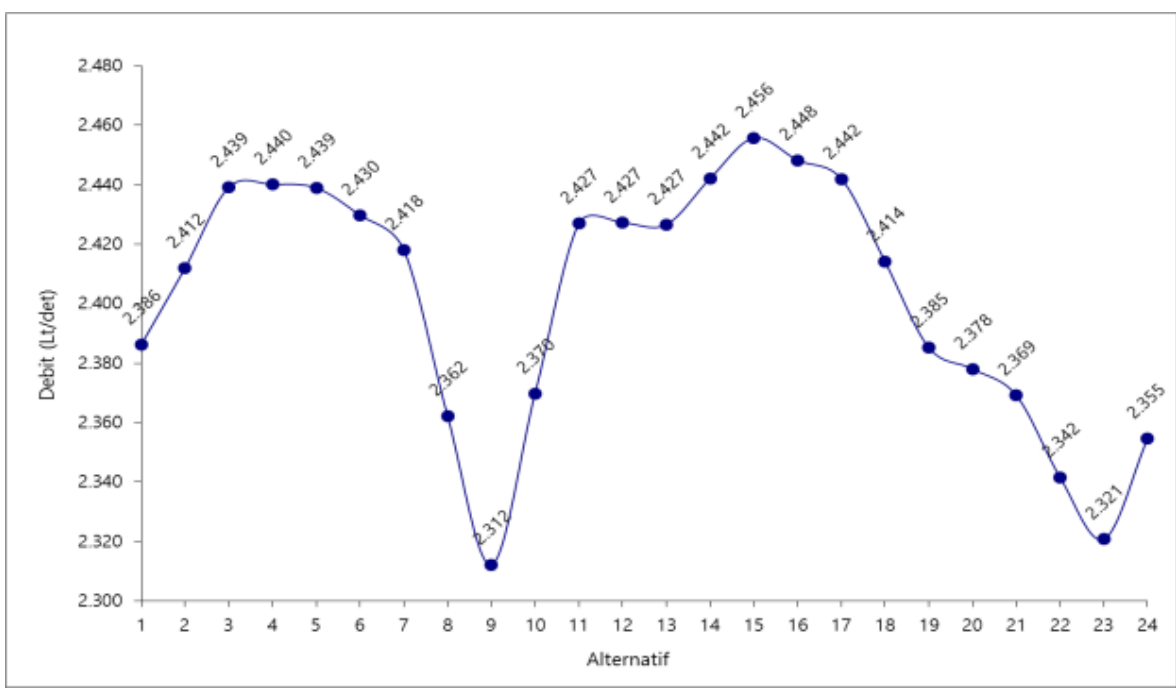

Gambar 9. Kebutuhan Pengambilan Per Hektar (Itr/det/ha) Penyaiapan Lahan 30 Hari.

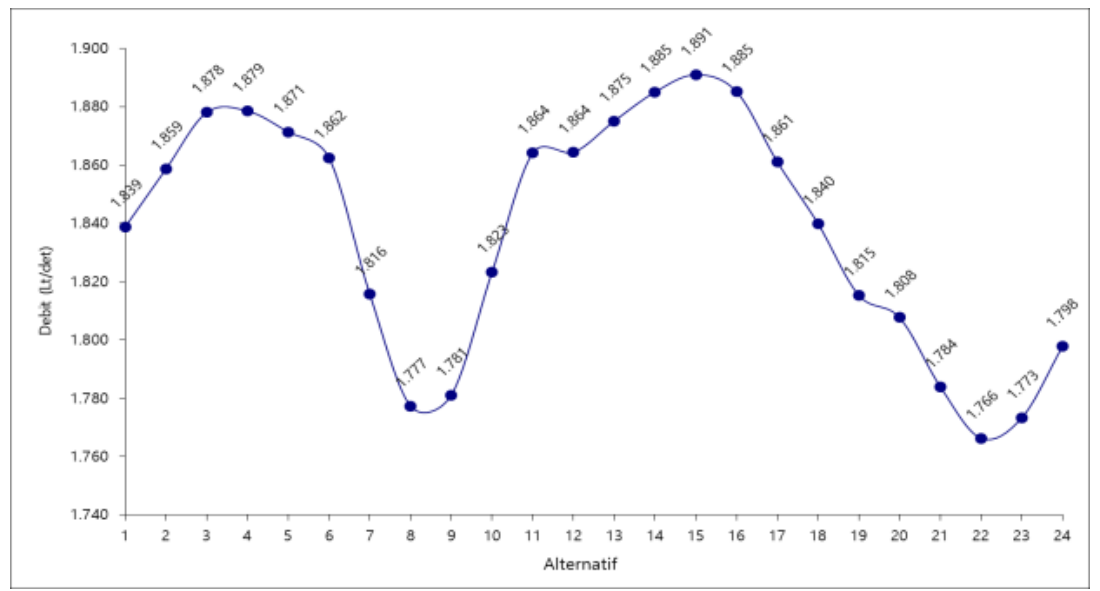

Gambar 10. Kebutuhan Pengambilan Per Hektar (ltr/det/ha) Penyaiapan Lahan 45 Hari.

Volume 1, No. 1, Januari 2015 


\section{KESIMPULAN DAN SARAN}

\section{Kesimpulan}

Berdasarkan analisis ketersediaan air pada daerah irigasi Blang Karam diperoleh debit pengambilan sebesar $2.312 \mathrm{ltr} / \mathrm{det} / \mathrm{ha}$ pada alternatif pola tanam dengan penyiapan lahan selama 30 hari dan kebutuhan pengambilan $0.925 \mathrm{~m} 3 / \mathrm{det}$ dan 1.766 ltr/det/ha pada alternatif pola tanam dengan penyiapan lahan selama 45 hari dan kebutuhan pengambilan $0.707 \mathrm{~m} 3 /$ det. Debit andalan yang tersedia dari Embung Blang Karam sebesar $1.15 \mathrm{~m} 3 /$ det. Hal ini menunjukkan bahwa ketersediaan air untuk daerah irigasi Blang Karam sudah cukup memenuhi untuk kebutuhan air irigasi dengan masa tanam selama 2 kali dalam setahun.

\section{Saran}

Berdasarkan hasil perhitungan dan analisis yang telah dilakukan, terdapat beberapa saran yang perlu dilakukan untuk menjaga keseimbangan air pada Embung Blang Karam yang digunakan sebagai sumber air baik untuk kebutuhan air baku maupun untuk kebutuhan air irigasi :

1) Perlu segera dilakukan studi dan survey lebih lanjut mengenai aspek kondisi topografi dan kondisi hidrologi setempat untuk mengetahui lebih lanjut ketersediaan air di dalam DAS pada Embung Blang Karam;

2) Perlu dilakukan studi, survey dan investigasi lebih lanjut untuk mencari dan mendeteksi semua sumber air yang baru (misal di bawah permukaan dan permukaan) sebagai pemenuhan kebutuhan air irigasi bahkan dapat diandalkan untuk kebutuhan air baku bila memungkinkan untuk itu;

3) Untuk mengatasi apabila terjadi kekurangan air dirasa perlu bagi pemerintah daerah setempat untuk segera melakukan penataan dan pendayagunaan kembali sumber daya air pada DAS di Embung Blang Karam khususnya dan seluruh Kabupaten Aceh Besar pada umumnya dengan menetukan kebijakan penggunaan air sesuai dengan tingkat kebutuhan masing-masing, melakukan studi potensi air tanah guna memenuhi kebutuhan air baku dan menambah debit limpasan dengan membuat tampungan air seperti embung dengan skala kecil sehingga kebutuhan untuk irigasi dan untuk kebutuhan sektor lainnya dapat terpenuhi setiap waktu.

\section{DAFTAR PUSTAKA}

Anonim 1, 2014, Laporan Akhir DED Daerah Irigasi Blang Karam, PT. Hidroteknik Andalan, Banda Aceh Soemarto,CD. 1999. Hidrologi Teknik. Jakarta : Penerbit Erlangga

Sholeh M. 1998. Hidrologi I. Diktat Kuliah. Surabaya : FTSP -ITS

Sosrodarsono S, dan Tominaga M, 1984.

Perbaikan dan Pengaturan Sungai. Jakarta : PT Pertja

USACE. 2000. Hydrologic Modelling System HEC HMS Technical Reference Manual. Maret 2000. 